\title{
How Do Policies and Actors' Attitudes, Interests and Interactions Influence Farmland Conversion Outcomes in Land-Use Planning?
}

\author{
Kristine Lien Skog \\ Department of Landscape Architecture and Spatial Planning, Norwegian University of Life Sciences, \\ P.O. Box 5003, NO-1432 Ås, Norway; kristine.lien.skog@nmbu.no; Tel.: +47-95017011
}

Received: 4 April 2018; Accepted: 5 June 2018; Published: 11 June 2018

\begin{abstract}
Conversion of farmland to built-up land threatens future supply of food and other ecosystem services. However, little research covers how different goods provided by farmland are taken into consideration in planning processes or how different actors influence land-use outcomes. This paper explores this by undertaking a comparative case study in two Norwegian municipalities. One of the main findings is that the national policies' emphasis on food security is not decisive for local farmland preservation decisions. The land-use plan of the municipality which has the strictest farmland conversion policy is guided by other local values, such as the farmland's provision of place identity and local food. In both municipalities, informal support networks of developers, other landowners, business interests, and politicians are established. Farmland preservation interests were less visible locally, and politicians found conversion proposals difficult to resist. The municipality which had converted most farmland was in favor of opening more land for development than needed. Then, the possibility space for development interest groups to influence land-use outcome increased. Findings indicate that farmland preservation policies require more emphasis on local public goods and inclusion of farmland preservation interests within the community. Further, farmland preservation strategies could benefit from linking agricultural policies and land-use planning, as well as more restrictive land-use planning.
\end{abstract}

Keywords: farmland conversions; land-use planning; attitudes; interest; interaction

\section{Introduction}

Vatn [1] warned that we are heading toward increased competition for land resources. An increase in built-up land seems necessary for a growing population, but so does the need for agricultural land. Urbanization trends are one of the major causes of the conversion of farmland to built-up land, in all regions of the world [2]. Farmland that has been converted to built-up land is considered irreversible. Farmland is a limited resource that is critical to a nation's food supply. Most of the remaining farmland is located where the building pressure is highest: around urban settlements, in central municipalities [3].

Land-use planning regulates how to accommodate population growth, and what land to build on, which occurs through both national and local policies in Norway. Planning is a social process that demonstrates ways of thinking, valuing, and acting formed by the participants [4]. Land-use planning structures can be characterized as institutions, where norms and formally sanctioned rules support certain values, and establish and protect various interests [1]. National land-use policies define the rationale for the local land-use planning process. Thus, national reasoning for farmland preservation polices, how they argue for farmland preservation, and their controlling mechanisms influence both local land-use planning processes and outcomes. In local land-use planning, local policies as well as local actors' attitudes, interests, and interactions influence the local land-use decisions. 
Farmland provides essential services for our society [5]; when farmland is converted, these values are diminished. Farmland benefits local farmers directly, as the basis of their income from agricultural production. For landowners who rent out their land, the economic interests of continued farming are equal to their rental income. Landowners also emphasize their contribution to food supply, their management of land for future generations, and their provision of multifunctional goods [6]. The importance of farmland both as a recreational landscape and as a place identity is acknowledged by local inhabitants $[7,8]$. However, we know little about how farmland values are reflected in land-use planning policies and argued by different actors, such as politicians, planners, landowners, inhabitants and developers.

Like many other countries [9], Norway's approach to land-use planning is considered liberal $[10,11]$. It is expected that market interests will have a great deal of influence on local land-use decision-making [12]. As local decision-makers (i.e., local politicians) have substantial room to maneuver when it comes to making formal farmland conversion decisions [13], informal "hidden" agreements between developers and owners of farmland present a challenge for farmland preservation [6]. To connect the different values to actors' attributes and their corresponding interests and influence in planning processes, both formal and informal processes should be included in research.

Local land-use processes engage different people with specific attitudes and interests to influence outcomes. Understanding these processes provides important input for farmland preservation policies. To identify sustainable planning practices across scales and actors, Geneletti et al. [14] called for research linking context to outcomes. Further, Bürgi et al. [15] emphasized the need for analyses that include actors and their networks of interaction to identify why and how cultural landscapes are changing. An institutional analytical framework can assist when addressing these gaps by linking planning contexts to actors, interactions, and specific land-use outcomes. The purpose of this paper is to determine how land-use planning policies and actors' attitudes, interests, and interactions influence farmland conversion decisions in local planning processes in Norway.

A comparative study of planning processes is conducted in two municipalities, one with a large amount of converted farmland and the other with far less. Given the liberal planning regime in Norway, where market interests have a major influence, actors' perception of monetary gains (private goods) might explain farmland conversion trends, while actors' perception of farmlands' multifunctional role (public goods) support farmland preservation outcomes.

\section{Theoretical and Analytical Framework}

When conducting research on the values that guide action in decision-making, we need to understand the underlying institutions [16,17]. Drawing on the work of sociological institutionalists such as Giddens [18] and March and Olsen [19], Buitelaar [16] argued that institutions are culturally defined, and their values are embedded in contextual meaning. Vatn [1] characterized institutions as formal and informal rules created by humans to guide action, for instance to handle conflicts in use of natural resources. Interactions among different actors in land-use planning processes are guided by these rules.

In the following, this article explores theoretical perspectives on potential values and interests that guide land-use policies, attributes and interests that guide actors in land-use planning processes, and lastly theoretical reflections on land-use interactions. Altogether, they contribute to a theoretical framework to analyze how policies and land-use planning processes influence land-use decision making.

\subsection{Farmland Preservation Values and Interests: Reasoning behind Policies and Practices}

Humans shape agricultural landscapes, and the multifunctional role of agriculture has been used since the late 1980s to describe the different natural and sociocultural values provided by agricultural production [20]. Perceived qualities in the landscape have been found to be relevant for land-use 
planning, as they can define binding rules for land-use change [21]. However, few studies address how they are reflected in decision-making and land-use planning [22,23].

The concept of ecosystem services has been useful when assessing landscape values for land-use planning [24]. Farmland is the basis for producing many ecosystem services (for instance, by producing food, fuel, and fibers), regulating services (such as water and climate), and supporting services (such as soil fertility), as well as for providing services such as recreation landscapes and place identities $[1,7,25]$. Both economic and non-monetary valuation should be included when assessing ecosystem services [26] and when managing cultural landscapes [27]. Cultural services, such as aesthetic values and recreation, are little covered $[23,28]$, but have been found to be relevant for people's appreciation of agricultural landscapes [7].

Bjørkhaug et al. [29] found that food supply has become the most dominant reason for Norway's farmland preservation policies, at the cost of the previous focus on agriculture's multifunctional role [30]. Land-use arguments rooted in the importance of food provision have also been found central in China and Europe, as well as in US and Canada [31-34]. In North America, two additional discourses also appear to be growing: the agrarian ideal as a rural identity builder and, from the environmental protectionists, an emphasis on ecology [33]. In Israel, Feitelson [35] found that the primary focus in farmland preservation policies was on the positive externalities provided by farmland, such as open space. However, these public goods were not connected to local land-use planning processes. Thus, additional research is needed to explore how different reasons for farmland preservation interests are articulated in different planning contexts [24].

\subsection{Actors' Attitudes and Interests}

In addition to values and interests argued in planning policies, attitudes and interests argued by different actors also impact land-use decisions. Given the potential benefits of both farmland preservation and conversion, tradeoffs (i.e., compromises) between different and/or conflicting interests are an important part of the decision-making. Bjørkhaug, Rønningen and Vinge [29] found that competing logics in farmland preservation policies-for example, residential purposes and private economic interests-lead to ongoing losses of both farmland and the ecosystem services that farmlands provide. However, these tradeoff analyses rarely include ecosystem services.

The unequal distribution of benefits and costs must be taken into account in sustainable management of cultural landscapes [36]. Bromley [37] distinguished between different beneficial interests: some are private while others are public. Public goods serve the wider society, referred to in the political sciences as "what is good for people and what people want for their well-being" ([20], p. 5). Farmland as recreational landscape, food supply, and place identity are examples of public goods [7], while the income farmers earn from farming is considered a private good [37]. Thus, preservation interests should include both public and private interests.

The potential costs of conversions also appear asymmetrical: those creating the problems do not necessarily experience the negative consequences of their actions [1]. For example, when farmland is converted, the landowner does not pay the cost of the country's decreasing food supply. As a free rider, they can buy food elsewhere. Owners may convert all their land and invest money elsewhere. This use might lead to negative externalities (e.g., reduced national food supply). However, collective goods can also be experienced in the local communities, such as loss of recreation and local food production when farmland is converted. Thus, those experiencing the costs of farmland conversions must be taken into consideration by those who make the local decisions in land-use planning, limiting or eliminating free rider situations.

\subsection{Land-Use Interaction}

The land-use policy process and the actors involved in the decisions interact to give rise to land-use decisions. An actor's capacity to influence political decisions is embedded in interactions guided by conventions and norms [1]. Thus, power is important to take into consideration when studying 
attitudes and interests and when researching how land-use outcomes are influenced. Jenkins [38] emphasized that power can be tracked by analyzing actors and their corresponding rules and resources. This can be understood as their way of defining reality and arguments in planning [39].

Land-use planning processes determine the relative strength of landowners' property rights-i.e., their right to manage their land without influence from others. Given the liberal land-use planning regime in Norway [40], both landowners and developers are expected to have a strong influence on land-use decisions, including farmland conversion. While landowners' involvement was previously connected to their role as farmers, as they sought protection of their land to continue farming, more than one out of ten landowners are now interested in farmland conversion [6].

Lawrence [41] also pointed to the need to include those with less power in institutional research. Farmers' voices are virtually unheard in land-use planning processes [33,42], as are the voices of environmentalists, planners, and ex-urbanites who want to protect the rural atmosphere, recreational values, and local influence on their own land-use [35]. According to Bunce ([33], p. 224), "this leaves us with the question of who really defines and controls the farmland preservation agenda and whose interests it really serves." Some researchers call for more involvement and place-specific considerations to promote sustainable planning regimes [43] and safeguard social learning [44]. Others argue for stronger governing at the national level [11,29].

\subsection{Analytical Framework}

The realization of farmland preservation policies depends on the ability of institutions to support sustainable choices in land-use planning practices. Ostrom [45] believes societies can be resilient when their institutions guide them to produce sustainable outcomes. This paper investigates whether institutional characteristics in two land-use planning processes can explain different farmland conversion outcomes.

Inspired by Ostrom's Institutional Analysis and Development Framework [46], a framework is developed for the purpose of this study (Figure 1). National and regional governance can be characterized as constitutional structures affecting local farmland conversion decisions. Hence, national, regional and local levels are incorporated in the framework. Context refers to physical and socioeconomic conditions and policies that guide action in land-use planning processes, described in detail in Section 3. Values and interests reflected in national and local planning policy documents refer to the first variable under study (see no. 1 and 2 in Figure 1). Because municipalities are responsible for most land-use planning in Norway, the main action arena is local land-use planning processes. Here, actors' attitudes and interests (3) are studied, as well as how they interact (4), and how they influence land-use outcomes (5). Regional and national authorities can proscribe or amend local land-use decisions if there are conflicting central regional or national interests. Therefore, land-use planning decisions can be negotiated at the regional level (6). If agreed on, final land-use decisions are brought back to the local level (5). If not, objections will be raised, and national authorities will take final decisions (7). 


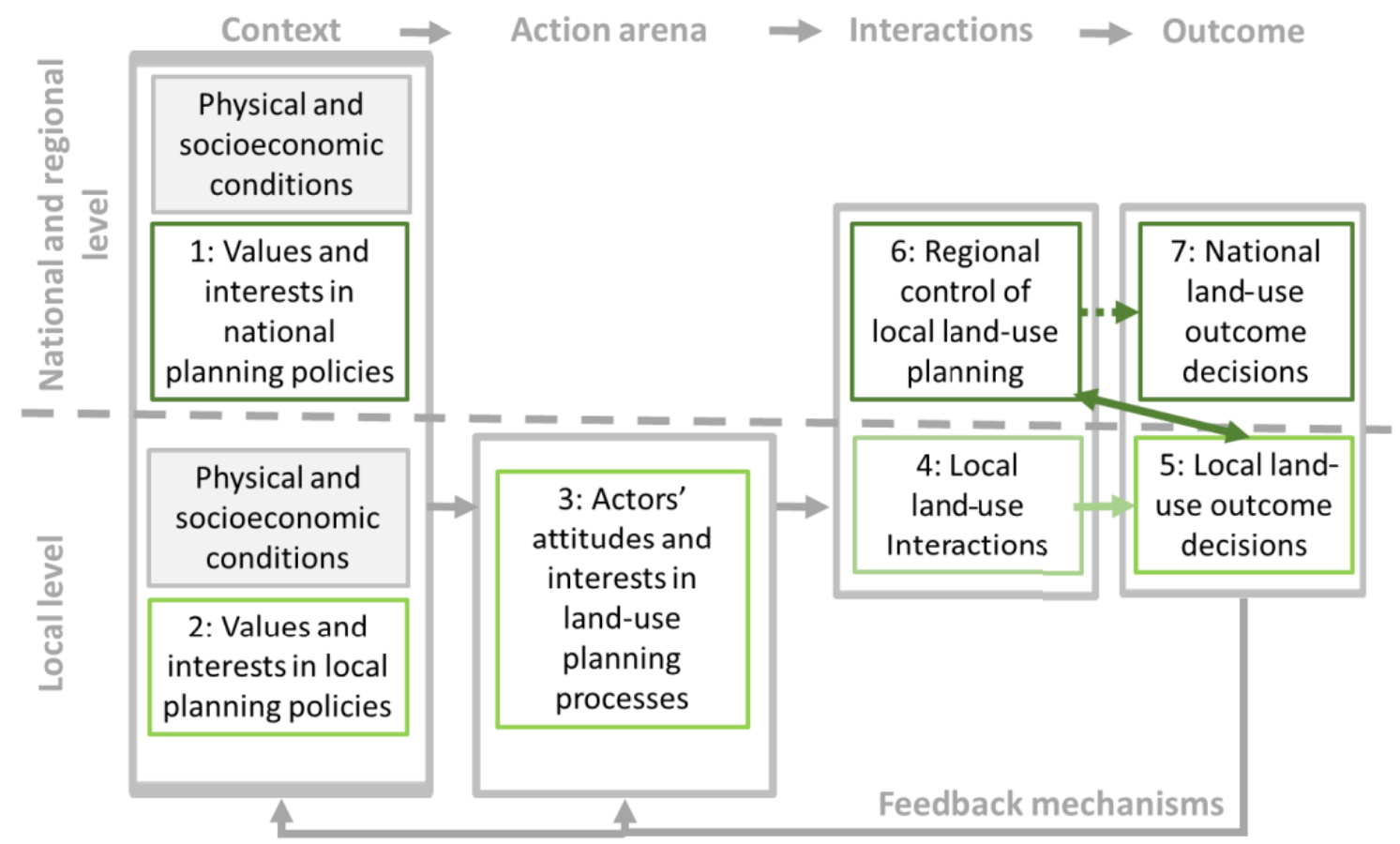

Figure 1. Analytical framework adapted from the Institutional Analysis and Development (IAD) framework [46].

\section{Materials and Methods}

\subsection{The Policy Context for Farmland Preservation in Norway}

Only three percent of total land in Norway is farmland; per capita, it is among the lowest of the OECD countries. Since 2004, the Parliament has sought to limit farmland conversions. However, 600 hectares of farmland were approved for conversion in 2016, surpassing targets to limit annual farmland conversion to less than 400 hectares by 2020 [47].

Land-use planning is regulated by the Planning and Building Act [48], which determines requirements for assessing and balancing costs and benefits and supporting sustainable development. National guidelines [49] derived from the act provide general directions that govern local land-use decisions, emphasizing compact building around public transport hubs, choosing alternative building sites other than farmland, and establishing green borders and agricultural zoning policies-all of which are challenging, as most farmland is located around urban settlement areas [3].

\subsection{Study Area}

A comparative case study of land-use planning processes in Rogaland County was conducted. Rogaland, located in the southwest of Norway, was selected because it is experiencing significant population growth while accounting for more than ten percent of Norway's total farmland, contributing substantially to the Norwegian food supply. To facilitate comparison, two polar cases of local land-use authorities and actors within Rogaland County were chosen to test the emergent theory of values, attitudes, interests, and interactions: Randaberg and Sola. The location of the county and two municipalities is shown in Figure 2. 


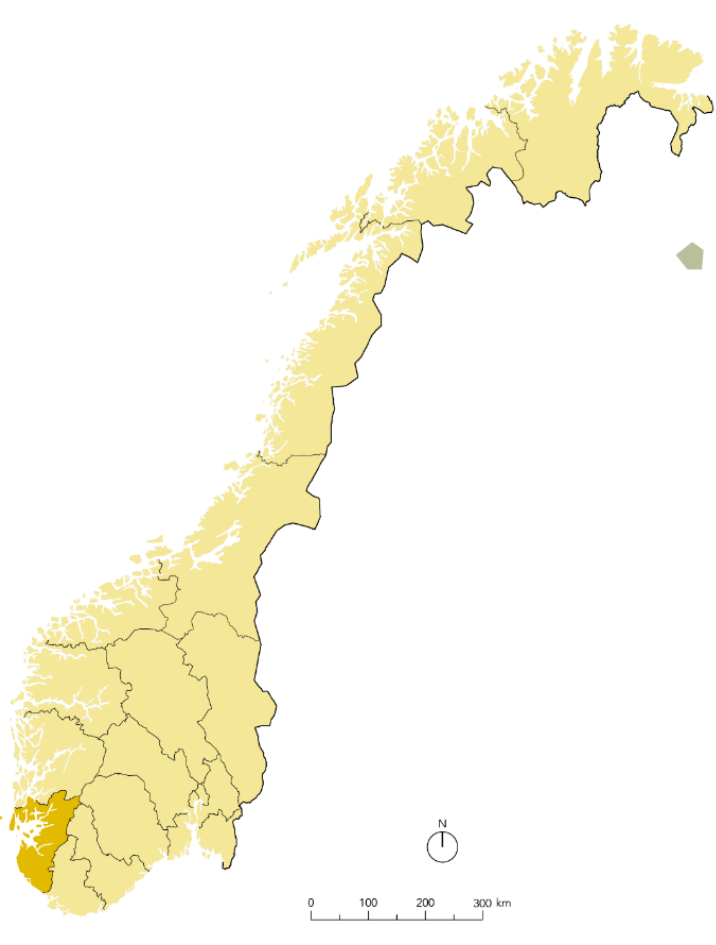

NORWAY

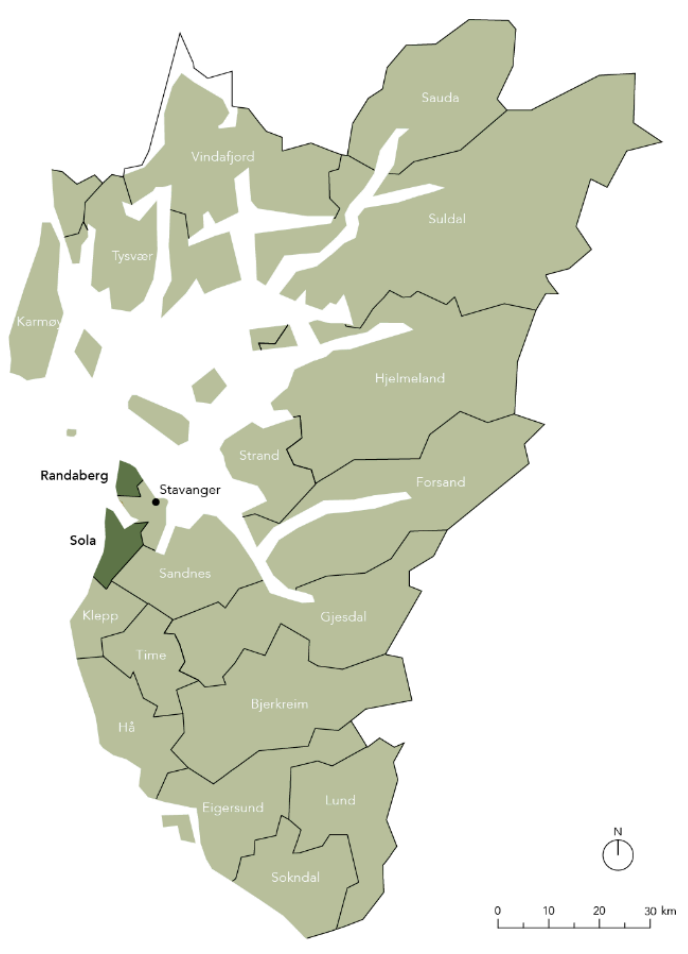

ROGALAND

Figure 2. The case region Rogaland County and its municipalities, including the case study municipalities of Sola and Randaberg, located north and south of the region's capital, Stavanger (Source: Nikolina Søgnen).

Sola has approved the most farmland conversions in Norway, shown by their reported zoning plans from 2005 to 2016, while Randaberg has approved much less (see Table 1). However, they are both a part of the continuous urban area around the city of Stavanger, which is experiencing high pressure to build. In addition, both communities are experiencing a relatively high loss of farm businesses, and agricultural land is a significant share of their total land.

Table 1. Study area profile (Source: Statistics Norway, Knudsen et al. [50]).

\begin{tabular}{|c|c|c|c|c|}
\hline & Sola & Randaberg & Rogaland & Norway \\
\hline Number of farm businesses 2016 & 151 & 65 & 4250 & 41,121 \\
\hline Cultivated land as share of total land 2016 (percent) & 47.3 & 56.7 & 54.7 & 3.2 \\
\hline Cultivated land in use 2016 (hectares) & 3239.2 & 1367.8 & $99,714.2$ & $983,660.8$ \\
\hline Inhabitants 2016 & 26,096 & 10,737 & 470,175 & 5,213985 \\
\hline Urban settlement land growth 2013-2016 (percent) & 2.2 & 0.3 & 3.9 & 2.1 \\
\hline Share of leased farmland 2014 (percent) & 61 & 59 & 33 & 44 \\
\hline Agricultural share of total Gross Domestic Product 2014 (percent) & 1.0 & 2.0 & 2.5 & $0.5^{1}$ \\
\hline
\end{tabular}

${ }^{1}$ Data from 2015.

\subsection{Methods}

Qualitative methods were used to explore links between planning values, human attitudes, land-use interactions, and outcomes. Haase et al. [23] recommended including actors with different perspectives. An advantage of focus group interviews is the ability to listen to open conversations. Actors with similar roles participated in the same interview. Eight focus group interviews were 
conducted in March 2016, with the following individuals: management leaders in the planning and agricultural divisions in Sola and in Randaberg (2); politicians of the planning board in Sola and in Randaberg (2); current and former political leaders of Rogaland County Municipality (1); managers in the agricultural and planning departments in Rogaland County and in Rogaland County Municipality (2); and NGO representatives from the regional farming and farmland preservation community (1). Altogether, 19 informants participated in the focus group meetings.

Landowners of farmland in the two municipalities also participated in individual interviews. To include different motivations, I interviewed landowners who believed that their land should be converted and those who wanted to continue active farming. Because their concerns were more personal, in-depth one-to-one interviews were conducted, based on the same interview guide used for the focus groups. Three individual interviews were conducted.

Each respondent received a semi-structured interview guide a few days in advance. The interviews lasted around two hours. At the beginning of each interview, I introduced the study and purpose of the meeting, and then asked interviewees to reflect upon several open-ended questions. They both considered their own interpretation and the attitudes, interests and interaction of others.

When analyzing the interviews, I wrote transcripts after listening to audio recordings. Further, findings related to various subquestions were abstracted and interpretations refined by identifying the main findings in the text materials and by reviewing the recorded meetings. Then, I included the results in a matrix covering responses from all respondents interviewed. Thereafter, I conducted a comparison of responses between the different focus groups and case municipalities. Finally, after a new review of the recorded meetings, quotations representative for illustrating the key findings were selected.

National farmland preservation policies were studied by analyzing how they are reflected in Parliamentary documents and national guidelines. Thereafter, the current master plans and planning proposals for Randaberg (for the period 2009-2022) and Sola (for the period 2015-2026) were analyzed. Planning documents were analyzed to map outcomes of planning decisions at various stages and identify how farmland values and preservation interests were reflected. All citations from interviews and documents are translated by the author. The two master plans, from 2009 and 2015, were approved according to the same national farmland preservation target, and land-use planning was run by similar national guidelines. However, the Norwegian Labour Party led the government in 2009, while the Conservative Party and its allies had taken over in 2015.

\section{Results}

This section begins with an analysis of values and interests that guide farmland preservation policies in national, regional, and local planning policies. Next, the attributes, interests, and relative influence of different actors are described, followed by a description of the interaction patterns among the dominant actors and current land-use planning outcomes in the two land-use planning processes.

\subsection{Farmland Preservation Values and Interests in National and Regional Land-Use Planning Policies}

Farmland preservation is mainly implemented by land-use planning policies. In the national farmland preservation strategy presented by the Norwegian government in 2014, food security was stated as the core reason for farmland preservation [51]. In 2015, the Parliament also acknowledged the importance of securing future food production as the main concern of the government's farmland preservation strategy [47]. As a follow-up to the national strategy, the Ministry of Food and Agriculture expects municipalities to manage farmland as a national interest [52].

Regional plans implement and map national land-use policies in the region, and guide local land-use planning. A regional plan was submitted in 2013 for Jæren, a part of Rogaland, covering ten municipalities in the region, including Stavanger (the region center), and our two case municipalities, Sola and Randaberg [53]. The protection of green and core agricultural areas were central objectives of this regional plan. Green borders and long-term agricultural zones were established. New land for 
development should be allocated outside the agricultural zones. All farmland preservation policies within the region must be in accordance with this plan.

The regional plan refers to both national and regional farmland preservation interests. The plan focuses on the region's favorable farming conditions. Emphasis is placed on the importance of food-related industry and regional food networks. Further, the plan states that guidelines for outdoor recreation activities within the agricultural zone can increase the understanding and appreciation of agricultural landscapes and farming activities, especially when they are located close to urban settlements.

\subsection{Values and Interests in Municipal Master Plans}

In the master plans of Sola [54] and Randaberg [55], farmland preservation is described as important for sustainable land-use management. Sola's vision emphasizes responsibility for future generations, while Randaberg's expresses a desire to build on their identity as a green village. Randaberg argues that they have village identities they want to build on: "A village is basically a cluster of farms where farmhouses are closely linked to a well, space, road or the like, where certain common properties and utilities aim to develop cooperative partnerships, for example in the harvest season" (p.6). Sola does not connect farmland or farming to their strategies for community development.

Sola's plan indicates a desire to avoid building in the agricultural zone. Randaberg states more directly that their new development will be outside the agricultural zone as defined in the regional plan. None of the municipalities specifically articulate how they will protect farmland outside these zones, but their planning documents imply different strategies. Sola allocates more land than needed to handle population growth. Randaberg only opened new areas that were specifically needed to accommodate their population growth. Sola planned for a higher population growth $(2.2 \%)$ compared to Randaberg $(1.2 \%)$. Sola's argument for their growth strategy is the expected continuation of economic growth that they want to participate in, while Randaberg states that they have to take responsibility for their share of the pressure for development.

In their master plan, the aim of Sola's business strategy is to participate in regional development by promoting competitiveness and economic growth. They describe agriculture businesses at the end of their business section, and it is not mentioned in the introduction. In Randaberg's plan, however, agriculture is central in the overall business strategy, as well as in an agricultural plan developed for the purpose. Randaberg defines concrete measures to further develop agricultural businesses, such as encouraging place-specific values stemming from local food and cultural goods in the landscape. Sola's plan mentions farmland as being valuable for food security. However, it is not referred to in the section covering social security and preparedness. In Randaberg's plan, food security is not mentioned at all. Food is described as a condition for a resilience and for development of local food systems.

Recreation values are mentioned once in Sola's plan, aiming to establish voluntary agreements between landowners and the municipality to develop biking and hiking trails. In Randaberg's plan, farmland and farming is directly linked to identity, ecosystem knowledge and public health, through active promotion of cultural landscapes and cultural heritage for tourism and recreation. The interaction between the citizen and the farmer is described as being important: "The long-term agriculture zone (40-year perspective) as set out in the municipal plan is not only a protection of farms and an external border for urban growth, but a green border that says 'welcome out into the cultural landscape'." (p. 95).

\subsection{Attitudes and Interests Influencing Land-Use Planning Processes}

In Rogaland County, there are many actors and corresponding attitudes and interests. In the following, informants reflect on the position of different groups relevant for local land-use planning processes; civil society, landowners, local politicians, developers, regional management, and the state will be described in separate sections. 


\subsubsection{Civil Society}

After consultation processes in Sola, the draft master plan received 34 responses outside of public authorities. Only two responses concerned resistance to farmland conversion proposals: one came from the local farming association, and the other from neighbors to one of the proposed conversions. In Randaberg, they received 25 responses from the civil society (some people sent multiple feedbacks). Seven responses concerned farmland preservation interests and losses of green landscapes, and four responses were from neighbors opposed to the proposed conversions.

All informants experience lack of personal involvement from the civil society in general, and also regarding farmland preservation interests. Politicians in Randaberg miss support from civil society when they seek to promote farmland preservation. They want things to stay as they are, meaning that the scattered housing policy should remain. In Sola, the politicians believe that the lack of involvement can be explained by migration: newcomers to the municipality have not inherited a place-specific farming identity. One politician in Sola expressed it as follows:

"There are usually neighbors who care about development issues. They will basically go barefoot straight into nature, so these are ulterior motives. Residents without a farm background do not understand farmland preservation. Property value matters most; it is mainly about one's own interests. Everyone is closest to himself."

One of the county representatives argues: "We have to articulate more than national food supply if we want to engage the civil society in farmland preservation issues."

However, all informants interviewed experience increasing farmland preservation awareness, although not yet articulated in land-use planning processes. This engagement has materialized in Randaberg; a private initiative to establish a farmland preservation monument has been strongly supported by the local politicians. Management in Rogaland County says that it is possible for civil society to gain power and influence in decision-making if they know how. Further, farmland preservation interests are very fragmented, which makes it difficult to influence land-use planning outcomes. One farmer in Sola emphasized that short timelines limit broader public involvement.

\subsubsection{Landowners}

Farmers interviewed in both Sola and Randaberg were mainly concerned with the importance of food production, and the pleasure of seeing large areas of brown, "undisturbed" soil. The importance of land for food production was also reflected among the NGOs interviewed. One farmer in Sola noted:

"I'm conservative, our soil is more than four-thousand-years-old, and that is many, many generations.

My grandfather was ideological and taught me about the huge and diverse life in the soil and that it provides food. It has become part of my spine."

According to management officials in Randaberg, farmers' alliances with the local community is of the utmost importance for long term farmland preservation. However, they perceive that most farmers are skeptical about opening up their land for the wider public; the farmers prefer to keep it private, and to limit access to outdoor recreation. This appeared to be especially prevalent in Sola. In Randaberg, some farmers appreciated being able to do more for the local community. For example, one farmer in Randaberg, who had recently taken over a farm, wanted others to benefit from its central location, with regards to the development of local farming businesses. The agricultural and farmland preservation organization NGOs interviewed also acknowledged other beneficial side effects of farmland, such as biodiversity and recreation.

All informants described the potential for enormous short-term income as an incentive for farmland conversion among landowners. NGO representatives described a shift in motivation. The pressure to build, paired with low income from farming and the unpredictability of the business, reduces farmers' motivation to continue farming; there is a trend toward fewer farmers thinking 
optimistically about the future. Structural changes, with fewer farmers and more rented farmland, play a large role in the current situation. Those leasing their land to farmers lose cultural and economic connection to their land, weakening the traditional linkages to family farming, and sometimes there are no children to take over the family farm. In these cases, the motivation to convert is stronger.

Management representatives in both Sola and Randaberg also explained that the smell and noise from farm operations lead to conflicts when they are located close to urbanized areas, when farmland is surrounded by houses. Additionally, all farmers interviewed have experienced challenges when investments are needed: if they rent a large amount of land at risk of farmland conversion, the bank is wary of giving them loans. Rogaland County representatives stated that farming today is a heavy burden on the farmer's shoulders, especially if their family does not support them. A farmer in Sola expressed it as follows: "The price I pay for being an active farmer and avoiding farmland conversion is my private life. Farming is unpredictable, but you get used to it."

\subsubsection{Local Politicians}

The county representatives say politicians mainly value farmland preservation for supply of food, which was also expressed by politicians in both Randaberg and Sola. One politician in Randaberg highlighted the fact that they were proud of making the first delivery of potatoes to Norway's royal family in the spring. One politician interviewed in Sola and another in Randaberg further reflected on the value of agricultural landscapes as providing recreation, being available for tourists, and supplying local food. The other politician in Sola, who came from a farm himself, expressed after a while: "I had not thought of this before!".

Interviewees in Rogaland County say it has been hard to gain acceptance for farmland preservation in the region based on its importance for farming businesses. Indeed, politicians interviewed in Sola stated that they often forget that their municipality actually is a farming community when dealing with land-use issues. According to them, politicians respect traditional farming values more in rural municipalities.

Politicians at the regional level argue that most local politicians are loyal to the agricultural zone defined in the regional plan, but that is only the case now, when there is still farmland available in the building zone. Politicians in Randaberg say they want to increase the agricultural zone and limit population growth. This is confirmed by the administration, but they also remarked that their strict farmland preservation policy is clear as long as it does not concern property owned by one of the politicians.

Politicians in Sola stated that the airport and other infrastructure in their municipality are heavy drivers for farmland conversion. In addition, politicians had to accept many development projects to cool down the housing market. As one said, "if we don't build houses, the society will collapse." The management representatives in Sola and the regional politicians characterize politicians in Sola as being quite liberal with regard to changing land-use, with less concern about farmland preservation. Landowners most often get licenses to convert their land for small-scale projects. Politicians in Sola were also observed as having personal and economic interests in a proposed project. According to the management and farmers in Sola, the conversion interests in Sola are in free play.

NGO representatives felt that politicians, in general, want growth, and are the most proactive to attract new development projects. When businesses are developed, municipalities need more houses, roads, and schools, which leads to more farmland conversion. Rogaland County representatives supported this assessment by saying:

"Municipal anxiety about not growing is high-in order to not have an aging population and to increase tax revenues, they fear growing less than neighboring municipalities. It is an important driver for farmland conversions: politicians want growth in all parts of the municipality." 


\subsubsection{Local Administration}

The municipal administration guides politicians in decision-making by preparing information and recommendations. Administrative representatives that handle the day to day administration of land-use planning policies in both Sola and Randaberg (heads of local land-use planning and agricultural divisions) mention farmland's importance for food supply first, followed by its multifunctional values with reference to food security, agricultural businesses, cultural landscapes, and the production of other goods for the whole society. According to these informants, farmland creates jobs and recreational experiences. However, the land-use planner in Randaberg said that she did not agree with the low population growth target set by the politicians.

The administrative representatives in both municipalities characterize their power to influence decisions as less than the local politicians. Local politicians stated that the local administration has some power; they can choose whether they want to follow up on inputs from the land-use planning process. According to the politicians, administration in the municipalities and at the county level follow each other's recommendations: "At any rate, if the political decisions are different from the administrative advice, the county will follow up on it." According to the NGO representatives, the administration has the power to define problems and articulate knowledge. However, the management in Sola did not prepare an environmental impact assessment of the farmland conversion proposals in their land-use planning process.

The local administration is divided into two divisions. The agricultural division is responsible for implementing agricultural policies, while the planning division implements land-use planning policies, including farmland conversions, as a part of their municipal planning process. Rogaland County characterized the cooperation between agricultural and planning divisions in Randaberg and Sola as good, but management in both municipalities might have limited timeframes.

The NGOs say farmland preservation policies suffer from the fact that agricultural divisions have been downsized in recent years: these divisions have a large amount of agricultural knowledge and values that are lost if they cannot intervene appropriately in the land-use planning process. Thus, this knowledge is seldom considered in decision-making.

\subsubsection{Developers}

Developers first and foremost support projects on farmland, as they want the land that is easiest to build on, according to the NGOs interviewed. Politicians in Sola also point to developers as an important player: they mainly promote projects on farmland. All informants noted that developers also want alternatives to farmland to build on, but these alternatives are limited and often valuable spaces for local recreation. Further, developers argued that many politicians hinder them from developing compact housing projects.

Regional politicians and the NGOs claimed that developers and economic interests are the most dominant in decision-making. Rogaland County management representatives stated that developers particularly exploit their space to maneuver inside the building zone. Here the market interests have the most power to influence land-use decisions. The politicians in Sola felt that whoever holds the money, holds the most power. This sentiment was supported by a farmer in Sola, who described how the preservation policy experiences challenges in urban areas. It is a battle between money and ideology, in which the money wins: "When the sky is the limit, the roadmap for farmland conversion is strong." Politicians in Sola pointed to developers' interests as being the most powerful, especially when the landowner supports their projects. Politicians in Randaberg also considered developers to be a powerful group.

\subsubsection{Rogaland County and the National Government}

All informants at the county level expressed food security as important for farmland preservation policies, but they also highlighted the importance of farming businesses and public goods, such as 
recreation and local food systems. However, they found it challenging when biodiversity or cultural heritage are in conflict with farmland preservation interests. One management representative of the Rogaland County expressed the conflicting values:

"The best experiences here are when farmland preservation and cultural heritage interests stand together. I am envying the management regime for cultural heritages. They have veto. They have a stronger protection regime. Farmland preservation policy is more up to the individual to decide from one case to another."

One politician in Randaberg supported this, saying: "It should be more important what we eat today, rather than what we ate one thousand years ago."

According to interviewees from the county administration, they believe they have limited power and never suggest anything; rather, they argued that it is the majority in the municipal council that holds the most power. The county might limit conversions inside the agricultural zone, but not in the development zone nor in decisions made outside the municipal planning regime. However, many informants pointed to the power that Rogaland County holds. According to the regional NGOs, the county has coordinated themselves and safeguarded a certain farmland preservation policy in the region; those interviewed felt that this policy is comprehensive and predictable.

County representatives also reported a decrease in control, as the Ministry of Local Government and Administration now wants them to limit the number of objections to local land-use decisions. More liberal governance gives municipalities more power; and thereby more power to market stakeholders. Politicians in Randaberg experienced little support from the county or the state, especially when they wanted to limit conversion in the development zone. The county representatives said local politicians are often silently happy when the county objects a farmland conversion proposal. Every local politician interviewed stated that it would have been extremely difficult to implement farmland preservation policies without firm control of their decision-making from higher levels of government.

NGOs interviewed and politicians in Randaberg both criticized the planning of transport projects governed by the national-level policies, arguing that they insufficiently consider the consequences for the farmland being built on. Farmland conversion practices in national transport projects provoked all the local politicians interviewed. Rogaland County representatives claimed this practice reduces their relative trust as state representatives in the region. One politician in Sola expressed the tensions:

"In small cases involving very small areas, the state makes it difficult for us. For example, they won't allow us to expand the golf course. It is incomprehensible when the transport corridor they plan for converts hundreds of hectares of farmland."

\subsection{Land-Use Planning Interactions}

All informants consider the number of purchase-option agreements as a strong first step in farmland conversion interactions in both Randaberg and Sola. Developers pay landowners to gain rights to build on their land. They distribute the land among themselves, knock on doors, and demonstrate their great financial capacity to realize their plans and establish option agreements. These interactions take place outside the public arena. According to one of the farmers, developers now have option agreements in approximately $99 \%$ of the building zone, and they have also spread out into the agricultural zones. This clearly shows that they are pushing for development on farmland, according to the county representatives.

Farmland preservation associations seemed surprised that farmers individually do not stand up in any official capacity for their farming interests. While some are active, most lose motivation. One of the farmers in Sola described the problem:

"Most of the landowners are ready to sell around the urban settlement areas; it is like an odorless poisonous gas that destroys the agricultural environment. Only a few there have invested in new 
barns. Suddenly you see the farm falls apart, the farmers stop producing food, and then it is easier to convert their land. Then you stop talking about the valuation of farmland and farming."

Option agreements put a good deal of pressure on local politicians. The landowners' power, according to informants from Rogaland County and regional farmer associations, is less overt than the developers' power: they talk to those they know beforehand-people with lot of informal influence in the political network. Thus, politicians seldom hear the voice of farmers that do not want farmland conversion during these processes. Most often, agreements are done and informal decisions are made without input from the wider society.

Rogaland County management representatives, regional politicians, and the NGOs say that many decisions are made behind closed doors between politicians and developers because there is substantial money in play. The developers know the politicians well, this was mainly emphasized in Sola. As one of the farmers in Sola said: "There are some guys in this system, especially in the largest municipalities, I know who they are. They have their own ideas and their own views." He described how politicians need to ally with developers: "If you have a shop, you want customers, then you want more people... It is like an invisible hand." He continued:

"Someone walks in a door, closes the door. There are not many there. When they go out, it will be as if they decided. The mayor has vital influence on these processes. Networks also exist outside formal meeting places-at bars, seminars, and so forth. The councilor can make as many investigations as they like. Those with strong political impact have financial interests. This is close to disqualification, sometimes maybe corruption. No one dares to uncover it, but there is much that cannot withstand the light of day."

Further, politicians in Sola often conduct political negotiations before political meetings, and find common ground there.

Rogaland County informants stated that residents have a good deal of indirect power because they vote. However, when "hidden" decisions are made before the land-use planning processes formally begin, it is difficult for residents to have any influence on land-use planning outcomes. According to the county representatives, the interaction processes are too complicated and residents get involved too late. In addition, the government wants efficient decision-making, which also limits the influence of actors who are not directly involved. The county representatives wondered if farmland preservation policies would have been different if residents had more influence on the decisions made.

\subsection{Land-Use Planning Outcomes}

When Randaberg approved their master land-use plan, they accepted 2.4 hectares of farmland for conversion to built-up purposes for the period 2009-2022, all inside their development zone. In Sola, the municipal master plan opened up for 13.7 hectares of farmland conversions for the period 2015-2026.

During the land-use planning process in Sola, politicians agreed on ten proposals inside the agricultural zone, all of them linked to option agreements between developers and landowners of farmland. Because these proposals were in conflict with the regional plan, the county raised objections. In a negotiation between municipality and county, in which one of the politicians with conflicting interests also participated, nine of the proposals were withdrawn. The county maintained its objection for the remaining proposal; although it was in conflict with the regional plan, the Ministry of Local Government and Modernization supported the municipality and rejected the county's objection.

A summary of the results in relation to attitudes, interests, interaction, and outcomes is provided in Table 2. 
Table 2. Summary of results from the two case municipalities.

\begin{tabular}{|c|c|c|c|}
\hline \multicolumn{2}{|c|}{ Characteristics } & Randaberg & \multirow[b]{2}{*}{ most reflected } \\
\hline \multirow{3}{*}{$\begin{array}{l}\text { Values and } \\
\text { interests in } \\
\text { land-use } \\
\text { planning policies }\end{array}$} & Nationally & Food security most reflected & \\
\hline & Regionally & \multicolumn{2}{|c|}{ Food security, agricultural business and agro-related industries, recreation } \\
\hline & Locally & $\begin{array}{l}\text { "Green village," place identity, local food } \\
\text { production, recreational } \\
\text { landscapes/tourism, farming business } \\
\text { strategies. }\end{array}$ & $\begin{array}{l}\text { Food security, recreational landscapes, } \\
\text { and agriculture (rarely mentioned) }\end{array}$ \\
\hline \multirow{7}{*}{$\begin{array}{l}\text { Actors' attitudes } \\
\text { and interests }\end{array}$} & \multirow{2}{*}{ Inhabitants } & \multicolumn{2}{|c|}{ Participate in decision-making when conversions threaten private interests. } \\
\hline & & Growing concern in the civil society. & Little concern. \\
\hline & Landowners & \multicolumn{2}{|c|}{$\begin{array}{l}\text { Farming business interests are strong, but not communicated in the land-use planning } \\
\text { process. The voice of farmers who do not want conversion is weak, landowners have } \\
\text { strong but "hidden" power in close cooperation with developers }\end{array}$} \\
\hline & Developers & \multicolumn{2}{|c|}{$\begin{array}{l}\text { Extensive power to facilitate option agreements for conversion rights with landowners, } \\
\text { and thereafter promote conversion proposals in the land-use planning processes. }\end{array}$} \\
\hline & \multirow{2}{*}{ Politicians } & \multicolumn{2}{|c|}{ Importance of food security and local society development. Formal power. } \\
\hline & & Restrictive planning regime. & $\begin{array}{l}\text { Liberal planning regime to facilitate } \\
\text { strong population growth and economic }\end{array}$ \\
\hline & Planners & $\begin{array}{l}\text { Restrictive planning both inside and } \\
\text { outside the agricultural zone. Planning } \\
\text { division wants more population growth } \\
\text { than politicians. }\end{array}$ & $\begin{array}{l}\text { Restrictive planning inside agricultural } \\
\text { zone, liberal in the building zone, little } \\
\text { attention to Environmental Impact } \\
\text { Assessments. }\end{array}$ \\
\hline \multirow{3}{*}{ Interactions } & National level & \multicolumn{2}{|c|}{$\begin{array}{l}\text { Liberal planning regime, strong power when conflicting sector interests are affected } \\
\text { (favoring transport). }\end{array}$} \\
\hline & Regional level & \multicolumn{2}{|c|}{$\begin{array}{l}\text { Liberal planning regime in building zones, strong power in agricultural zone and when } \\
\text { other environmental interests are involved (biodiversity and cultural heritage). }\end{array}$} \\
\hline & $\begin{array}{l}\text { Local land-use } \\
\text { planning } \\
\text { processes }\end{array}$ & $\begin{array}{l}\text { Administration and politicians meet with } \\
\text { developers, but restrictive land-use } \\
\text { planning limits developers' influence and } \\
\text { relative power in decision making. Civil } \\
\text { society participation is limited. }\end{array}$ & $\begin{array}{l}\text { Early and hidden interaction between } \\
\text { developers, landowners, and politicians; } \\
\text { politicians notice to some degree } \\
\text { conflicting interests when it comes to final } \\
\text { decisions. Civil society participation is } \\
\text { weak. }\end{array}$ \\
\hline \multicolumn{2}{|c|}{ Outcome } & $\begin{array}{l}\text { Approved conversion of } 2.4 \text { hectares of } \\
\text { farmland for the period } 2009-2022 \text {. } \\
\text { Amount of licensed conversions equals } \\
\text { what was needed to facilitate the planned } \\
\text { population growth. No projects accepted } \\
\text { in the agricultural zone. }\end{array}$ & $\begin{array}{l}\text { Approved conversion of } 13.7 \text { hectares of } \\
\text { farmland for the period 2015-2026. } \\
\text { Licensed more land than needed to } \\
\text { support growth targets, including ten } \\
\text { projects (with option agreements) in the } \\
\text { agricultural zone. Only one remained } \\
\text { after negotiations in the county; } \\
\text { the Ministry supported this conversion. }\end{array}$ \\
\hline
\end{tabular}

\section{Discussion}

In this paper, land-use planning processes correspond to institutions, where values and interests are supported by norms and rules in use [1]. The objective of this section is to determine which working rules might explain farmland preservation outcomes with regards to planning policies, actors' preferences, and interaction.

\subsection{Values and Interests in Planning Policies}

McClintock [56] argues that cities will preserve farmland only when the production of food is considered a public good and access to it is considered a right. Farmland preservation policy is mainly communicated as being in the interest of the nation's food supply, not by the possible provision of wider multifunctional goods from farmland and farming. This has also been identified as a national agricultural discourse [57]. However, this might be a sectoral limitation when implementing various ecosystem values in practice [22].

When studying the land-use decisions in this area of Norway, it appears that the national value of farmland for food supply was overruled by the local public values (such as recreation 
and place identity), in the municipality with the most restrictive farmland preservation practices. Thus, by connecting the public values provided by farmland to the local scale, farmland preservation values and interests might be taken more into account in decision-making. Despite the relative importance for local farmland preservation interests $[7,58]$, the link between national and local public values is missing in national land-use planning policies.

Planning following national guidelines can be rather instrumental, and to some extent disconnected from local realities [59]. The regional plan is primarily territorial in the way it targets a green zone for preservation. The plan does not connect farmland, agricultural business, and the wider society. The relative willingness to convert within the regional building zones opens a fast track for development without any limitations in time and space. The distribution of borders illustrates the relative power of different interests, also demonstrated elsewhere [60]. It is there until a new border is established. Informants wondered what will happen when all farmland is converted within the development zone. That is a good question.

The maintenance of ecosystem values that benefit the local society has been found important for sustainable land-use planning [7,22], which also emerged as a theme in this study. Agriculture and farmland is vital to Randaberg's identity as a "green village", while Sola's valuation of farmland is closer to what is reflected in national planning policies. For instance, national food supply, as communicated in Sola's plan, is replaced by local food production in Randaberg. Further, the relative importance of farming is different in the two municipalities, and Randaberg connects farming closer to their business development strategy. In Sola, however, a willingness to build on farmland and promote growth eclipses these qualities. Thus, as previously mentioned, linking the public interests of both economic and non-economic values at the local level seems crucial [27].

\subsection{Farmland Preservation Attitudes, Interests and Interaction in Local Land-Use Planning}

A close connection between agricultural landscapes and inhabitants was acknowledged in planning documents (in keeping with previous research) [7,61]. However, although farmland preservation interests appear stronger in Randaberg, participation from the society is limited in both Randaberg and Sola. One reason is the lack of engagement from the general public; people only act when their private interests are threatened, corresponding to the collective action problem [62]. Another reason might be, despite a few examples, the farmers' sole cultural focus on productivity: they feel that they are surrounded by residents who do not appreciate their farming business. This might limit the potential for benefitting from public values as a part of their business strategy. As for national policies, the importance of food production was emphasized the most.

The various conflicts and lack of mutual attitudes and interests between farmers and other farmland preservation interests might lead to increasingly fragmented power within farmland preservation interests in land-use planning processes, as has been demonstrated in previous research $[29,33,35,42]$. Leased land further strengthens these patterns; farmers rent much of their cultivated land, and they are dependent on a good relationship with landowners to ensure long-term contracts which may silence their voice when a landowner wants conversion [42]. Lack of motivation for continued farming reduces their investment interests, thereby eliminating the argument for politicians to preserve their land. These patterns occurred in both municipalities covered in this study.

Farmland preservation arguments reflected by politicians in the two case municipalities are, to a certain extent, equal when it comes to farming and agricultural landscapes. However, their views of their right to limit private land property interests are very different, as are, correspondingly, the ways in which they open up for urban development market interests. In Sola, the municipality most willing to convert their farmland, development interests increased the power of the formal and informal interactions in order to influence land-use planning outcomes.

Another finding from the present study is that private purchase-option agreements present a major challenge to farmland preservation [6]. When option agreements enter the scene, the landowner's power is "hidden" and used in informal interactions. The developers act in both formal and informal 
arenas, together with a wider network of business interests that benefit from growth. If politicians have personal or economic interests in conversion proposals, they might also have a strong say in these informal interactions. If decisions are made informally before the official public land-use planning processes begin, interactions mainly include private interests and values in the decision-making. Further, the potential of inhabitants and farmers to influence outcomes is limited. Although not directly connected to farmland conversion, similar patterns of interactions have been identified in previous research $[10,12]$. This might explain why the local politicians supported ten proposals inside the agricultural zone in Sola, even though they were in conflict with their own planning objectives.

\subsection{Implications for Governance}

Legitimacy is important when understanding land-use changes in farmland preservation policies [35]. The politicians interviewed clearly felt loyal to the people that elected them. However, in the formal and informal planning processes, they mainly meet with market actors that support farmland conversion; farmers and inhabitants with a public interest in continued farming are absent. Politicians found this challenging when they wanted to promote a stricter farmland preservation policy. Local politicians face local realities rather than national party policies [13].

Lack of public involvement is a general challenge in land-use planning, threatening Norway's general democratic values regarding participation $[12,63]$ as in other regions of the world. Communicative interaction and bottom-up planning, as defined by Giddens [18] and Healey [64], might in principle support public interests [65,66] and the inclusion of ecosystem service values [21]. Based on findings regarding limited public participation, this opportunity is not taken advantage of in current farmland preservation policies. Lack of participation and involvement from civil society further strengthened this pattern and unevenly distributed power. Decisions became less transparent, social sanctioning systems seemed weak, and thereby also diminished the potential for learning to promote more sustainable outcomes in the future. However, given the asymmetric distribution of power (with increased farmland conversion as a side-effect) and the enormous economic and self-driven economic interests in play, this path seems difficult to avoid.

Randaberg implemented a strict farmland preservation policy both inside and outside the agricultural zone by restricting conversion of land to only that which would accommodate a limited population growth. In Sola, a more expansive policy for population growth led to support of private interests and more farmland available for conversion. More restrictive land-use policies could limit the amount of farmland "in play", and thereby the relative power of local market interests and elevate the benefits of farming businesses and local place making.

Compared to the Labour government in charge when Randaberg approved its master plan in 2009 , the conservative government had a more liberal practice of the existing land-use rules and regulations when Sola approved its plan in 2015. Given the current liberal national governance [11], local decision-making and market interests have strong influence on land-use planning outcomes. Findings in this paper illustrate the importance of connecting farmland preservation interests to the recognition of its provision of local public values. Governance should strengthen local participation to better reflect public values and interests in local societies. People who prepare land-use regulations should be more aware of the informal rules they create for interaction and decision-making [16]. Agricultural and planning policies could benefit from being more closely integrated in local land-use planning. The results demonstrate that the future success of farmland preservation policies lies in a shift in justifications to include more local farmland preservation values and farming actors' attitudes and interests [67].

Saarikoski et al. [22] found that multi-level governance is needed to take advantage of both controlling regimes and local ecosystem attributes and knowledge. However, this study indicates that politicians might take less farmland preservation responsibility when they expect regional or national authorities to limit local decisions that allow farmland conversion. Thus, given the controlling mechanism in place, compliance with national farmland preservation policies requires strong control. 
Today's liberal practice of proscribing and amending local land-use decisions might contribute counterproductively [68]. Proposal for stronger land-use control, as argued by Bjørkhaug et al. [29], can be considered as a supplementary recommendation.

Acknowledgments: This study has been conducted as a part of the food program commissioned and financed by the Norwegian University of Life Sciences (NMBU). I would like to thank Timothy Kevin Richardson, Arild Vatn and Erling Berge at NMBU and Christy Anderson Brekken at Oregon State University for useful comments and feedback.

Conflicts of Interest: The author declare no conflict of interest.

\section{References}

1. Vatn, A. Environmental Governance: Institutions, Policies and Actions; Edward Elgar Publishing: Cheltenham, UK, 2015.

2. FAO; ITPS. Status of the World's Soil Resources (SWSR)—Main Report; Food and Agriculture Organization of the United Nations and Intergovernmental Technical Panel on Soils: Rome, Italy, 2015.

3. Skog, K.L.; Steinnes, M. How do centrality, population growth and urban sprawl impact farmland conversion in norway? Land Use Policy 2016, 59, 185-196. [CrossRef]

4. Healey, P. Traditions of Planning Thoughts; Blackwell Pulishing: Oxford, UK, 2012.

5. Barthel, S.; Isendahl, C. Urban gardens, agriculture, and water management: Sources of resilience for long-term food security in cities. Ecol. Econ. 2013, 86, 224-234. [CrossRef]

6. Skog, K.; Bjørkhaug, H. Farmland under urbanization pressure: Conversion motivations among landowners in Norway. 2018; submitted.

7. Skog, K.L.; Brattestå, A.C.; Thomassen, M.M. Agricultural landscapes in urbanization processes: Empty spaces or resources for urban place making? Kart Og Plan 2016, 76, 252-262.

8. Zasada, I. Multifunctional peri-urban agriculture-A review of societal demands and the provision of goods and services by farming. Land Use Policy 2011, 28, 639-648. [CrossRef]

9. Sager, T. Neo-liberal urban planning policies: A literature survey 1990-2010. Prog. Plan. 2011, 76, 147-199. [CrossRef]

10. Hanssen, G.S.; Falleth, E.I. Market-oriented urban planning-constraining citizen participation. Local Gov. Stud. 2014, 40, 403-428. [CrossRef]

11. Strand, A.; Næss, P. Local self-determination, process-focus and subordination of environmental concerns. J. Environ. Policy Plan. 2017, 19, 156-167. [CrossRef]

12. Falleth, E.I.; Hanssen, G.S.; Saglie, I.L. Challenges to democracy in market-oriented urban planning in Norway. Eur. Plan. Stud. 2010, 18, 737-753. [CrossRef]

13. Hamre, L.; Hanssen, G.S.; Skog, K.L. Jordressursar under press: Kan partipolitikken forklara gapet mellom det nasjonale målet for og den lokale forvaltinga av jordressursane? Eng: Farmland under pressure: Can party politics explain the gap between the national target and the local management of farmland? Norsk Statsvitensk. Tidssk. 2018, in press.

14. Geneletti, D.; La Rosa, D.; Spyra, M.; Cortinovis, C. A review of approaches and challenges for sustainable planning in urban peripheries. Landsc. Urban Plan. 2017, 165, 231-243. [CrossRef]

15. Bürgi, M.; Verburg, P.H.; Kuemmerle, T.; Plieninger, T. Analyzing dynamics and values of cultural landscapes. Landsc. Ecol. 2017, 32, 2077-2081. [CrossRef]

16. Buitelaar, E. Zoning, more than just a tool: Explaining houston's regulatory practice. Eur. Plan. Stud. 2009, 17, 1049-1065. [CrossRef]

17. Ostrom, E. Background on the institutional analysis and development framework. Policy Stud. J. 2011, 39, 7-27. [CrossRef]

18. Giddens, A. Modernity and Self-Identity: Self and Society in the Late Modern Age; Stanford University Press: Stanford, CA, USA, 1991.

19. March, J.G.; Olsen, J.P. Rediscovering Institutions; Simon and Schuster: New York, NY, USA, 2010.

20. Dwyer, J.C.; Short, C.J.; Berriet-Solliec, M.; Gael-Lataste, F.; Pham, H.; Affleck, M.; Courtney, P.; Déprès, C. Public Goods and Ecosystem Services from Agriculture and Forestry - A Conceptual Approach; Project report; Pegasus Institute for European Environmental Policy: London, UK, 2015. 
21. La Rosa, D.; Privitera, R.; Martinico, F.; La Greca, P. Measures of safeguard and rehabilitation for landscape protection planning: A qualitative approach based on diversity indicators. J. Environ. Manag. 2013, 127, S73-S83. [CrossRef] [PubMed]

22. Saarikoski, H.; Primmer, E.; Saarela, S.-R.; Antunes, P.; Aszalós, R.; Baró, F.; Berry, P.; Blanko, G.G.; Goméz-Baggethun, E.; Carvalho, L. Institutional challenges in putting ecosystem service knowledge in practice. Ecosyst. Serv. 2018, 29, 579-598. [CrossRef]

23. Haase, D.; Larondelle, N.; Andersson, E.; Artmann, M.; Borgström, S.; Breuste, J.; Gomez-Baggethun, E.; Gren, Å.; Hamstead, Z.; Hansen, R.; et al. A quantitative review of urban ecosystem service assessments: Concepts, models, and implementation. AMBIO 2014, 43, 413-433. [CrossRef] [PubMed]

24. Niemelä, J.; Saarela, S.-R.; Söderman, T.; Kopperoinen, L.; Yli-Pelkonen, V.; Väre, S.; Kotze, D.J. Using the ecosystem services approach for better planning and conservation of urban green spaces: A finland case study. Biodivers. Conserv. 2010, 19, 3225-3243. [CrossRef]

25. Swinton, S.M.; Lupi, F.; Robertson, G.P.; Hamilton, S.K. Ecosystem services and agriculture: Cultivating agricultural ecosystems for diverse benefits. Ecol. Econ. 2007, 64, 245-252. [CrossRef]

26. Hasse, J.E.; Lathrop, R.G. Land resource impact indicators of urban sprawl. Appl. Geogr. 2003, 23, $159-175$. [CrossRef]

27. Hernández-Morcillo, M.; Bieling, C.; Bürgi, M.; Lieskovský, J.; Palang, H.; Printsmann, A.; Schulp, C.J.E.; Verburg, P.H.; Plieninger, T. Priority questions for the science, policy and practice of cultural landscapes in europe. Landsc. Ecol. 2017, 32, 2083-2096. [CrossRef]

28. Plieninger, T.; Bieling, C. Resilience and the Cultural Landscape: Understanding and Managing Change in Human-Shaped Environments; Cambridge University Press: Cambridge, UK, 2012.

29. Bjørkhaug, H.; Rønningen, K.; Vinge, H. A situational analysis of the material and non-material forces shaping the protection of farmland in Norway. In Frogs, Fuel, Finance or Food? Cultures, Values and Ethics in the Management of Agricultural Land; Bjørkhaug, H., McMichael, P., Muirhead, B., Eds.; Toronto University Press: Toronto, ON, Canada, 2018; in press.

30. Bjørkhaug, H.; Richards, C.A. Multifunctional agriculture in policy and practice? A comparative analysis of Norway and Australia. J. Rural Stud. 2008, 24, 98-111. [CrossRef]

31. Tan, Y.; He, J.; Yu, Z.; Tan, Y. Can arable land alone ensure food security? The concept of arable land equivalent unit and its implications in zhoushan city, China. Sustainability 2018, 10, 1024. [CrossRef]

32. Tan, R.; Beckmann, V.; van den Berg, L.; Qu, F. Governing farmland conversion: Comparing China with the Netherlands and Germany. Land Use Policy 2009, 26, 961-974. [CrossRef]

33. Bunce, M. Thirty years of farmland preservation in North America: Discourses and ideologies of a movement. J. Rural Stud. 1998, 14, 233-247. [CrossRef]

34. Wilton, B. Farmland preservation perspectives In Farmland Preservation: Land for Future Generations, 2nd ed.; Caldwell, W.J., Hilts, S., Wilton, B., Eds.; University of Manitoba Press: Winnipeg, MB, Canada, 2017.

35. Feitelson, E. Social norms, rationales and policies: Reframing farmland protection in Israel. J. Rural Stud. 1999, 15, 431-446. [CrossRef]

36. Bürgi, M.; Bieling, C.; von Hackwitz, K.; Kizos, T.; Lieskovský, J.; Martín, M.G.; McCarthy, S.; Müller, M.; Palang, H.; Plieninger, T.; et al. Processes and driving forces in changing cultural landscapes across Europe. Landsc. Ecol. 2017, 32, 2097-2112. [CrossRef]

37. Bromley, D.W. Environment and Economy: Property Rights and Public Policy; Basil Blackwell Ltd.: Oxford, UK, 1991.

38. Jenkins, R. The ways and means of power: Efficacy and resources In The SAGE Handbook of Power; Clegg, S.R., Haugaard, M., Eds.; Sage: Thousand Oaks, CA, USA, 2009; pp. 140-156.

39. Flyvbjerg, B. Rationality and Power: Democracy in Practice; University of Chicago Press: Chicago, IL, USA, 1998.

40. Falleth, E.I. Introduksjon til norsk planlegging. In Utfordringer for Norsk Planlegging; kunnskap, bærekraft, demokrati; Aarsæther, N., Falleth, E., Nyseth, T., Kristiansen, R., Eds.; Cappelen Damm Høyskoleforlaget: Kristiansand, Norway, 2012.

41. Lawrence, T. Power, institutions and organizations. In The Sage Handbook of Organizational Instutionalism; Greenwood, R., Oliver, C., Sahlin, K., Suddaby, R., Eds.; Sage: London, UK, 2008; pp. 170-197.

42. Horne, T.B. Agricultural Land Preservation Challenges as a Result of Rental Farming. Master's Thesis, Norwegian University of Life Sciences, Ås, Norway, 2017. Available online: https://brage.bibsys.no/xmlui/ handle/11250/2453999 (accessed on 9 June 2018). 
43. Kleemann, J.; Inkoom, J.N.; Thiel, M.; Shankar, S.; Lautenbach, S.; Fürst, C. Peri-urban land use pattern and its relation to land use planning in Ghana, West Africa. Landsc. Urban Plan. 2017, 165, 280-294. [CrossRef]

44. Berkes, F.; Colding, J.; Folke, C. Navigating Social-Ecological Systems: Building Resilience for Complexity and Change; Cambridge University Press: Cambridge, UK, 2008.

45. Ostrom, E.; Ahn, T.K. The meaning of social capital and its link to collective action In Handbook of Social Capital. The Troika of Sociology, Political Science and Economics; Tinggaard Svendsen, G., Haase Svensen, G.L., Eds.; Edward Elgar Publishing: Cheltenham, UK, 2009; pp. 17-35.

46. Ostrom, E. Institutional rational choice: An assessment of the Institutional Analysis and Development Framework. In Theories of the Policy Process, 2nd ed.; Sabatier, P., Ed.; Westview Press: Boulder, CO, USA, 2009.

47. Standing Committee on Business and Industry. Innst. 56s (2015-2016)_Vedlegg 4, Recommendations to the Storting from the Standing Committee on Business and Industry; Parliament; Standing Committee on Business and Industry: Oslo, Norway, 2016.

48. Planning and Building Act. Law no. 71. 27 June 2008.

49. Ministry of Local Governent and Modernisation. Statlige Planretningslinjer for Samordnet Bolig-, Areal- $O g$ Transportplanlegging; Vol. Fastsatt ved kgl. res. av 26.09 2014, jf. plan- og bygningsloven av 27. juni 2008, § 6-2; Ministry of Local Governent and Modernisation: Oslo, Norway, 2014.

50. Knudsen, H.; Haukås, T.; Kvamme, S.; Gjøtvold-Solbu, K.; Lerfald, M. Verdiskaping i landbruk og Landbruksbasert Verdiskaping i Rogaland; NIBIO-Rapport, 2 (75). 2016. Available online: https:// brage.bibsys.no/xmlui/bitstream/handle/11250/2390933/NIBIO_RAPPORT_2016_2_75.pdf?sequence=5 (accessed on 9 June 2018).

51. Ministry of Food and Agriculture. Prop. 127 s (2014-2015) Jordbruksoppgjøret 2015-Endringer $i$ Statsbudsjettet 2015 m.m; Ministry of Food and Agriculture: Oslo, Norway, 2015.

52. Ministry of Food and Agriculture. Follow up of the National Farmland Preservation Strategy-Letter to Regional Authorities and Local Municipalities 8 March 2016; Ministry of Food and Agriculture: Oslo, Norway, 2016.

53. Rogaland City Council. Regional Plan for Jæren 2013-2040; Rogaland City Council: Stavanger, Norway, 2013.

54. Sola municipality. Municipal Master Plan 2015-2016; Sola Municipal Council: Sola, Norway, 2015.

55. Randaberg Municipality. Municipal Master Plan 2009-2022; Randaberg Municipal Council: Randaberg, Norway, 2009.

56. McClintock, N. Radical, reformist, and garden-variety neoliberal: Coming to terms with urban agriculture's contradictions. Local Environ. 2014, 19, 147-171. [CrossRef]

57. Vinge, H. Food security, food sovereignty, and the nation-state. In Food Sovereignty in International Context: Discourse, Politics and Practice of Place; Trauger, A., Ed.; Routledge: Abingdon, UK, 2015; pp. 99-115.

58. La Rosa, D.; Barbarossa, L.; Privitera, R.; Martinico, F. Agriculture and the city: A method for sustainable planning of new forms of agriculture in urban contexts. Land Use Policy 2014, 41, 290-303. [CrossRef]

59. Healey, P. Making Better Places-The Planning Project in the Twenty-First Century; Palgrave Macmillian: Basingstoke, UK, 2010.

60. Hongslo, E. Background information or future vision? Mapping wild reindeer landscapes in a planning process. Landsc. Res. 2017, 42, 349-360. [CrossRef]

61. Hahn, T.; Heinrup, M.; Lindborg, R. Landscape heterogeneity correlates with recreational values: A case study from Swedish agricultural landscapes and implications for policy. Landsc. Res. 2018, 43, 696-707. [CrossRef]

62. Rydin, Y.; Pennington, M. Public participation and local environmental planning: The collective action problem and the potential of social capital. Local Environ. 2000, 5, 153-169. [CrossRef]

63. Knudtzon, L.C. Kampen om et strandsoneareal-et diskursperspektiv på en arealbruksbeslutning. Kart Og Plan 2013, 73, 367-381.

64. Healey, P. Institutionalist analysis, communicative planning, and shaping places. J. Plan. Educ. Res. 1999, 19, 111-121. [CrossRef]

65. Vatn, A. Institutions and the Environment; Edward Elgar Publishing: Cheltenham, UK, 2007.

66. Ostrom, E. Governing the Commons: The Evolution of Institutions for Collective Action; Cambridge University Press: Cambridge, UK, 1990. 
67. Wang, Y. Negotiating the farmland dilemmas: 'Barefoot planners' in china's urban periphery. Environ. Plan. C Gov. Policy 2015, 33, 1108-1124. [CrossRef]

68. Tenbrunsel, A.E.; Messick, D.M. Sanctioning systems, decision frames, and cooperation. Adm. Sci. Q. 1999, 44, 684-707. [CrossRef] 